Светлана Б. Панић ${ }^{*}$

Универзитет у Источном Сарајеву

Филозофски факултет Пале

Катедра за србистику

https://doi.org/10.18485/ai_zsjoski.2019.2.ch16

821.163.41.09-31 Петровић Г.

811.163.41'367.625

\title{
СИНТАКСИЧКЕ ФУНКЦИЈЕ ГЛАГОЛСКОГ ПРИДЈЕВА ТРПНОГ У РОМАНУ ОПСАДА ЦРКВЕ СВ. СПАСА ГОРАНА ПЕТРОВИЋА
}

Глаголски придјев трпни већ својим називом указује на двије функције - глаголску и придјевску. Глаголска функција везана је за пасивну дијатезу, а придјевска за функцију атрибута. Литература још није изнашла јасне критеријуме диференцијације тих двију функција. Али, то нису једине функције глаголског придјева трпног, него се оне на својеврстан начин укрштају у функцији предикатског апозитива.

Циљ овог рада је да се на примјерима из романа Опсада цркве Св. Спаса Горана Петровића освијетли употреба глаголског придјева трпног и препознају контекстуални критеријуми њихове диференцијације.

Кључне ријечи: трпни глаголски придјев, атрибут, предикатски апозитив, пасивна дијатеза, именски предикат

1. Поријекло глаголског придјева трпног води од пасивног партиципа претерита, чиме се објашњава његова „хибридна” природа и данашња сачуваност и у придјевској и у глаголској употреби. Глаголска употреба

* svetlana.b.panic@gmail.com 
овог облика у савременом српском језику подразумијева функцију предиката пасивне реченичне форме, док се његова семантичка вриједност правог придјева синтаксички јавља у функцији атрибута или предикатива. Али, то нису једине функције глаголског придјева трпног, него се оне на својеврстан начин укрштају у функцији предикатског апозитива.

У литератури се до сада издвајају два правца истраживања - „поједини лингвисти су се усредсређивали на то да утврде морфо-семантичка обележја глаголаิ чији трпни придеви развијају значење и функцију правих придева (Белић 1934; Белић 1937; Стевановић 1962), док су други у фокус стављали конструкцију са трпним придевом и глаголом $\delta u \bar{u} u$, утврђујући притом када се њоме изражава пасивна дијатеза, а када трпни придев функционише као именски део предиката” (Јовановић 2013: 203).

1.1.Када је ријеч о атрибутској функцији и значењу трпног глаголског придјева, Литература која нам је била доступна не показује јасну усаглашеност крите-

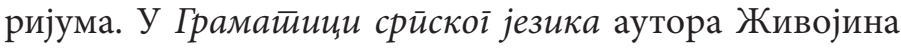
Станојчића и Љубомира Поповића налазимо да у придјевској служби „трпни глаголски придев има све особине придева: значи сталну особину, има деклинацију, облике неодређеног и одређеног вида, компарацију" (2014: 407). Александар Белић инсистира на наглашавању семантике и сматра да „сваки пасивни партицип може постати у атрибутској употреби обичан придев, ако му то однос његова значења према именичком значењу допушта" (Белић 1937: 130), односно транспозиција трпног придјева у прави придјев, према Белићу, остварује се на начин да пасивни партицип „губи временску ознаку и почиње да значи сталну особину” (Исто: 130). „Али када се пасивним партиципом, оним који је упо- 
требљен атрибутски и који не може никако да добије значење резултативности, већ остаје са својим значењем пасивног вршења радње - скраћује каква реченица, ту пасивни йарйиции значи време и има и даље партиципско значење”. Ђорђић је унеколико подударан, али се и разликује: „1) Трпни придеви у предикативној употреби као формални атрибути образовани су од свршених глагола. 2) Стоје углавном иза речи коју одређују. 3) Имају неодређени, именски облик. 4) Често се даду изразити и релативном и експликативном реченицом. 5) Показују радњу или стање објекта које је постало пре радње реченичног предиката и које је у своме последњем стадијуму или резултату истовремено са радњом предиката. Од тих особина једна од најбитнијих јесте неодређени облик трпног партиципа када стоји у предикативној служби" (1931: 122).

Оно што можемо извести као заједничке имениоце попридјевљења или категоријалног транспоновања трпног глаголског придјева из литературе своди се на неколико критеријума, од којих су формалнограматички:

1. деклинација,

2. одређени придјевски вид, те

3. референцијална предсупстантивна позиција,

док се сематички истиче резултативност, односно критеријум према коме лексема у ужем реченичном контексту означава сталну особину, што обухвата случајеве и кад је категоријално транспоновани трпни придјев дио терминолошке синтагме.

1.2. Укрштање атрибутске и адвербијалноодредбене функције у функцији предикатског апозитива (или 
предикативног атрибута ${ }^{1}$ в врло фреквентно остварује се захваљујући глаголском придјеву трпном. „U funkciji Pat-a pojavljuju se determinativne reči (kao i sintagme), pre svega pridevi, kako pravi tako, i znatno češće, glagolski, s obzirom na to da je ova pozicija u starijim tipovima srpskog književnog jezika bila ekskluzivno participska" (Суботић/ Петровић 2000: 1151-1152). Карактеристике функције предикатског апозитива су: „а) 'заступа' кондензовану (скраћену) зависну реченицу, у којој је вршио функцију лексичког језгра именског предиката, због чега - уколико је придјевског типа - придјев мора бити у неодређеном виду, б) да има двоструку синтаксичку и семантичку зависност: према именичком или замјеничком субјекту или објекту и према глаголском предикату, в) да је особина изражена предикатским апозитивом актуелна само у времену реализације радње предиката, и г) да није семантички маркиран, тј. да његова форма сугерира само то да је особина која се приписује лицу, предмету или појави - од извјесног значаја за реализацију онога што означава реченични предикат - било да та особина као паралелна предикација - у неком смислу употпуњава информацију коју предикат носи - или да утиче на саму реализацију онога о чему реченични предикат информише" (Ковачевић 2015: 48-49).

1.3. Чисто предикатска функција трпног глаголског придјева односи се на пасивну дијатезу и она подразумијева да „име појма које би у реченици са активним обликом глагола било у функцији йравоі објекйа - представља се као средиште реченице и тако постаје

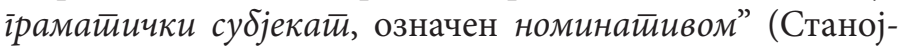
чић/Поповић 2014: 129). Осим овога пасивној дијатези

1 Више о самом термину предикатски апозитив, као и о самом одређењу ове функције види у Ковачевић 2015. 
приписује се и карактеристика динамичности која је посебно важна за пасивне облике са трпним глаголским придјевом и „подразумијева постојање процеса у ситуацији која се исказује предикатом у времену коме се та ситуација приписује" (Танасић 2012: 72). Литература је потпуно сагласна да је пасивна дијатеза условљена искључиво прелазним глаголима, односно глаголима који рекцијски нужно захтијевају навођење директног објекта, а обухваћена су оба глаголска вида.

2. Језик романа Ойсаga иркве Св. Сйаса подражава средњовјековни стил йлеиеније словес, онеобичење је најизразитије у погледу лексике, а архаични призвук израза постиже се изузетно фреквентном употребом глаголских придјева и прилога, односно савремених облика који воде поријекло од некадашњих партиципа. Циљ нашег рада управо је испитивање семантичко-синтаксичког статуса трпног глаголског придјева у овом роману.

3. Однос атрибутске и предикатскоапозитивне функције глаголског придјева трпног

3.1. У роману Oйcaga uркве Св. Сйаса пронашли смо велики број примјера ${ }^{2}$ категоријално транспонованог глаголског придјева трпног који према претходно одређеним критеријумима заузимају чисто атрибутску функцију:

... носећи копља са стегом злайовезеноі Христовог знамена... (9); ... након бдења и навршене полуноћнице... (9); Старци умиљених срца (11); ... чија се врева сливала

2 Сви примјери преузети су из Г. Петровић, Ойсaga иркве Св. Сйаса, Београд: Политика, Народна књига, 2004. 
на главни трг, већ подобро испуњен надвикивањем продаваца птица, сушених урми, зјала, шимавлених кожа, мелема... (16-17); Метлом од увезане брезове шибљике он стаде сабирати прашину... (39); За домом Спасовим кренуше и трпезарија, мађерица, (...) делови ниског манастирског бедема са йризияаним келијама (62); ... по обријаним главама Кумана (111) итд.

Осим што су испуњени сви формалнограматички критеријуми, сематички трпни глаголски придјеви у овим примјерима показују сталне особине супстантива који им је надређен. У примјеру Метилом оg увезане $\delta р е-$

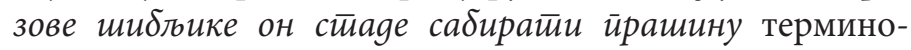
лошки фразеологизам брезова метила није „декомпонован" у облик метила og брезовине, og брезове шиблике, него се у средишту синтагме експлицира члан који је најредундантнији у процесу настајања коначног фразеологизма брезова метила, па се оваква употреба трпног придјева може образложити искључиво стилским разлозима. Такође се у примјеру За gомом Сйасовим кренуше и йриезарија, мађерица, (...) gелови нискоі манастичрскоі беgема са иризияаним келијама истиче карактер процесуалности, односно аутор трпним придјевом скреће пажњу да келије ту нису биле првобитно планиране него су накнадно зидане, јер глагол йризиgайи значи

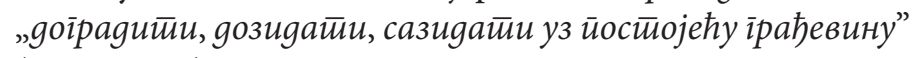
(PMC: 1023).

3.2. Међутим, уочили смо много већи број примјера у којима би требало испитати постојаност и оправданост постављених критеријума атрибутске употребе трпних придјева. Анализу намјеравамо урадити упоређивањем примјера са глаголским придјевом трпним у позицији предикатског апозитива. Предикатски апозитив подразумијева, дакле, реченични члан који је уведен преко 
предиката, њиме се реферише о особинама субјекта или објекта те о карактеру глаголске радње:

Царица Филипа, зачуђена, уздрхта... (14); Све је то, спрва расуйо по дворишту, лагано налазило своју службу у грађевини (25); Оиеерана, немоћна да се врати, магла се маховито вила по околини... (30); Занетеи послом, монах пропусти да барем гледне кроз отворен прозор (39); Домаћин их прими осмехнуши... (40); Увређен, великоименити господин одлучи да се освети што суровије може (43); ... који је, ништа не слутећи, јахао ирриљубльен уз неоседланог, белог коға (49); И мада се већина држала чврсто, нейољьљьана, ... (68); ... како ниже старих докова, занетии дивљим загрљајем, у читавом врелу мехурића страсног подавања и узимања, бестидно пливају одрази.... (76); ... Стефан је горео, оиххрван љубавном грозницом... (80); Из клупка устаде и млинар, али некако сав йроменен, као без људске својине (88) итд.

Код овако употријебљених трпних придјева јасно је да они држе чврсту везу са предикатом реферишући о радњи која је претходила оној означеној предикатом и на неки начин утицала на њу, али истовремено и о привременом стању које се приписује супстантиву са којим трпни придјев истовремено остварује синтаксичку релацију. Из тога би се могло закључити да је ту ријеч о скраћивању реченице у којој би трпни придјев био дио предикатске конструкције, као нпр. $\rightarrow$ Великоименитии іосйоgин оялучи gа се осветии шйо суровије може јер је био увређен.

3.3.1. Имајући то у виду, покушаћемо анализирати и примјере у којима се трпни глаголски придјев јавља уведен преко супстантива и према до сада утврђеним критеријумима његова чисто атрибутска употреба не би требало да се доводи у питање. Ријеч је о употреби трп- 
ног глаголског придјева у зависном падежу и у облику одређеног придјевског вида.

\section{У примјерима:}

Иза ове туште вукла се тма уздуваних саветника ... (33); ... два доушника, изобличених лица, сада с крвавим ранама уместо очињег вида, преклињаху: - Милост, господару! ... (36); ... три мајстора нађоше жену која је у свом сну већ чекала крај расиремљене колевке (47-48); Док се припрема зеље, чорба од корена боце или какво друго вариво, може да се прича, чак је безазлен разговор, између две усне, добродошла врста зачина. Али, у замешеном се тесту није смела наћи ниједна реч (54); Ходао је тешко, (...) не растајући се од једног дугачког штапа којим се помагао, па ипак, зачудо, ни у расквашеној земљи не остављајући трагове стопала (56); ... насликани Пантократор је йоgиіннуйом десницом благосиљао окупљене (67) итд.

као дијелови атрибутског израза јављају се трпни глаголски придјеви које Речник Майиие срйске не издваја као посебне придјеве, дају се само облици инфинитива. У неким од примјера попридјевљени глаголски трпни придјев стоји и као једини атрибут уз супстантив, што значи да се налази у идентификационој, референцијалној улози, која додатно потврђује његову атрибутску функцију, а осим тога већином одговарају и на питање какав, а не који. Ипак, уколико се узима у обзир резултативност, иако је у свим издвојеним примјерима употријебљен попридјевљени трпни глаголски придјев од глагола свршеног вида, чини се да особине које се приписују супстантивима нису сталног карактера, него више привременог, што се подудара са сематичким одређењем функције предикатског апозитива. Осим тога, они, ипак, чувају и своју релацију према предикату, као у примјеру

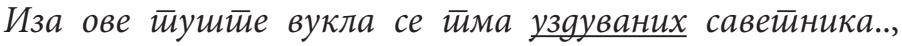


у коме се јасно види веза трпног придјева узgуваних са глаголом вукла се, гдје трпни придјев задржава и нијансу узрочног значења (вукли су се јер су били уздувани).

У реченици ... gва gоушника, изобличених тии, саяа с крвавим ранама уместио очиғеі̄ вияа, ӣреклиғаху: -

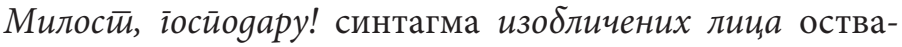
рује тројаку синтаксичко-семантичку релацију - према супстантиву gоушник преко које је уведена остварујући функцију неконгруентног атрибута са значењем карактеристичне појединости, у којој трпни придјев заузима позицију обавезног детерминатора, затим са синтагмом саgа с крвавим ранама уместио очинеі вияа у којој се даје подробнији опис појма изобличен, али и са глаголом ирреклињаху у предикату, према коме остварују чак двоструку семантику - пропратне околности и имплицитно узрока, јер се може схватити да су лица изобличена и од страха и очаја, не само од физичке унакажености. Полисемантичност трпног придјева овдје остварује стилски компресованију слику.

Значење пропратне околности може се имплицитно препознати захваљујући трпном глаголском придјеву и у примјеру... йри мајсйора нађоше жену која је у свом сну већ чекала крај расиремлене колевке. Оно је овдје потпомогнуто партикулом већ, са којом синтагма крај расиремљене колевке остварује метафоричку сематичку вриједност прилога ( $\bar{u} о \bar{u} \bar{u} y н)$ с сиремно уз глагол је чекала, или уколико би био употријебљен придјев сирремна, онда би он остваривао функцију предикатског апозитива.

Метафорично истицање налазимо и у примјеру Али, у замешеном се йесйу није смела наћи нијеgна реч. Издвојена реченица мора се посматрати у контексту са претходном, од које је у ствари само стилистичким поступком парцелације и одвојена и има значење $\mathrm{Kag}$ се йестио меси (каg їа монаси месе), айсолуйно се не сме 


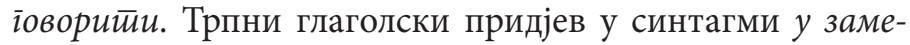

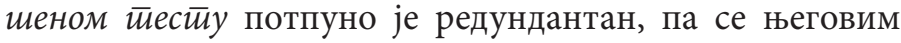
навођењем истиче временска семантичка компонента будући да је ту ријеч о редукованој зависној временској реченици (Kag je йесйо замешено), при чему он означава стање „које је постало пре радње реченичног предиката и које је у своме последњем стадијуму или резултату истовремено са радњом предиката” (Ђорђић 1931: 122).

У примјеру Хоgао је йешко, (...) не растиајући се оg

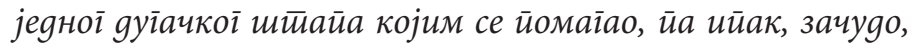
ни у расквашеној земљи не остиављајући йраїове стиойала трпни глаголски придјев не кореспондира са глаголом у предикату, али ипак задржава везу са глаголом не остиављајући, који у овом случају врши функцију адвербијалне одредбе начина које трпни придјев раскващеној стилски додатно истиче својом допусном семантиком, тако да се цијелом реченицом остварује контраст као стилска фигура.

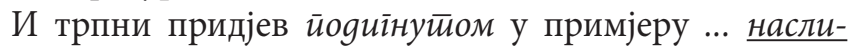

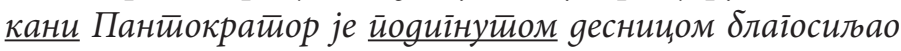
окуйлене у основном, информативном слоју јесте подразумијевајући, редундантан податак. Осим тога, будући да је ријеч о икони, атрибут приписан супстантиву gecница требало би схватити као трајну особину. Међутим, наводећи редундантно изражено попридјевљеним трпним придјевом актуализује се тренутак и он добија на динамици, посебно ако се има у виду Псалм 136, у коме се говори о Богу који дјелује „руком крепком и мишицом подигнутом” (Библија 2007: 530), такође са наглашавањем самог тренутка дјеловања.

Иако се дакле синтаксички потпуно понашају као прави придјеви, за овако употријебљене трпне придјеве не може се рећи да су прешли потпуни семантички еволутивни пут до правог придјева. 


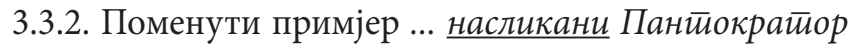

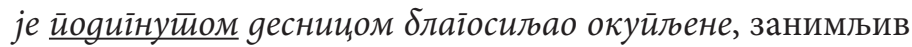
је и по трпном глаголском придјеву насликани употријебљеном у функцији атрибута. Одређени облик придјевског вида такође је један од критеријума према коме се може установити чисто придјевска, атрибутска семантика и функција трпног глаголског придјева. Међутим, ако замијенимо у овом случају конгруентни атрибут насликани неконгруентном конкурентном формом са слике ( са иконе), чини се да се тиме на неки начин губи извјесна динамичност и нијанса допусног значења које носи израз са трпним придјевом ( $\rightarrow$ иако / је само био/ насликан), без обзира што је употријебљен у одређеном придјевском виду и тиме блокиран да се интонативно одвоји од супстантива и прецизније заузме функцију предикатског апозитива. Иако, дакле, овај трпни придјев стоји уз супстантив у функцији субјекта, он чува своју везу са глаголом у предикату и самим тим и своје глаголске особине. За овакву употребу - употребу трпних придјева у облику одређеног придјевског вида уз супстантив у субјекту - у нашем корпусу забиљежили смо бројне примјере:

Од пола Смилецове речи, не веће од мувљег упљувка, изговорене овлашно, скраја тржнице, кварила се тек уловљена дунавска риба... (33); Пренеражени израз лица боље је од речи говорио... (35); ... уgатене речи су се спајале... (44); Препуче и један насликани бокал. Прсну живоиичсана вода. ... А три заљуљана звона заборавише да су од туча, хтедоше из куле да полете (60); Возглас се јаче вину, а йевани псалам се разли... (61); Поіођена сума за најам галија од осамдесет пет хиљада сребрних келнских марака није била у потпуности исплаћена... (72); Покренуйе мрачне бујице су све лагано одвлачиле ка усамљеној воденици (88); Свака изіоворена реч има своју вредност (92); Издужише вратове извезени двоглави орлови (94); Напољу се расушени лебдећи бусенови стадоше трошити.... (125) итд. 
У сваком од ових примјера, без обзира на облик одређеног вида, трпни придјев остварује двојаку везу - он се формално везује за супстантив у функцији субјекта, али истовремено он изражава и радњу која је претходила радњи глагола у предикату и на неки начин утицала на њега. Трпни глаголски придјев у овом случају може се развити у посебну зависну клаузу, најчешће зависну адвербијалноодредбену, али и атрибутску ( нпр. $\rightarrow$ Найољу се тебgећи бусенови стиаgоме тиромииии јер су били расушени/јер су се расушили). Његова веза са предикатом није толико јака као кад би се он у неодређеном облику употријебио и интонативно одвојио, те тако заузео чисту позицију предикатског апозитива $-\rightarrow$ Найољу

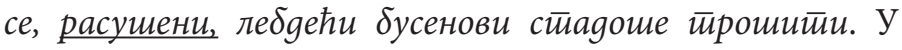
овом случају би била израженија семантика приписивања квалификације привременог стања, а у реченичном контексту тај би члан комуникативно био најнаглашенији. Овако, он је са предикатским апозитивом подударан у сематици приписивања неке карактеристике „imenskom referentu u poziciji subjekta ili objekta u toku realizacije predikatske radnje" (Суботић/Петровић 2000: 1150). Осим тога, у овом примјеру трпни глаголски придјев образован је не од прелазног него од повратног глагола, али свршеног вида, што се подудара са досадашњим резултатима истраживања, „јер само се код њих може говорити о двојаком пореклу особине изражене трпним придевом" (Ђорђић 1931: 144).

3.3.3. На сличан начин функционишу у корпусу и трпни глаголски придјеви употријебљени у синтагмама уз супстантив у функцији објекта, за шта такође биљежимо бројне примјере:

... чувају расуйе месечине (12); ... као када јато пољских дрпаваца рашчепрка расушене купе кртичњака (30); ... а 
вредне селице размотавају йоgвијене крајеве неба... (43); ... обесно поскидао извезене двоглаве орлове... (43); ... појци су скупљали расуйе тропаре и кондаке... (54); ... повлачећи ону ногу обувену у чизму са заденутим пером гаврана... (56); .... невољко оставио, стохватим страстима ӣрейушйеної, самог господара (58); Слепи дужд је са прамца заповедничког брода топлио свој схлађени поглед на ватри што је гутала бедеме луке несретног града (79); ... нису могли да одговоре озлоблено $і$ Стефана од ове женидбе (80): ... против таквих је увек пио воде йреливане преко црнокорастог ножа... (87); Из клупка устаде потуљена прилика, надланицом отирући зацењен осмех и истиеіннуйе бале (88); Понесте ли, како сам и рекао, оне наше хаљине шивене платном од заветрине из Хиландара? (141) итд.

Ни у овим примјерима за трпне глаголске придјеве не може се рећи да су потпуно категоријално преобразовани нити да у својој резултативности означавају сталну особину. Њихова чврста веза са супстантивом у функцији објекта је неспорна, међутим, без обзира на одређени придјевски вид или позицију у односу на надређени супстантив, њихова веза са глаголом и даље је уочљива - сематички је то узрок (... чувају расуие емесечине $\rightarrow$ чувају месечине јер су расуйе), допуштање (....

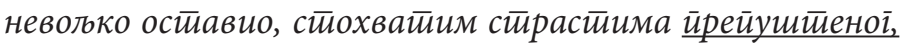
самої їосйоgара $\rightarrow$ осйавио је їосйоgара иако је он био йре-

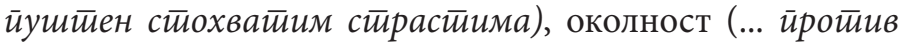

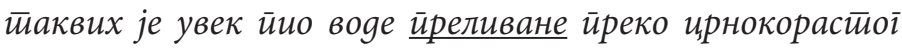
ножа...) и сл, односно „партицип добива глаголске особине чим се доведе у везу са предикатом" с тим што се наглашава да „то за собом повлачи, као што је показано, и промену места и облика" (Ђорђић 1931: 122). Промјена мјеста и облика у овом случају даје трпном глаголском придјеву несумњиве глаголске особине, које трпни придјев у мањем интензитету ипак задржава у предепозицији и у одређеном придјевском виду. 
3.3.2.1. Оваква употреба трпног глаголског придјева додатно је истакнута уколико је трпни придјев праћен прилогом, за шта у корпусу биљежимо бројне примјере:

Задржаше га четири најеgном испружене руке... (36); Али, у замешеном се тесту није смела наћи ниједна реч. Поготово не она олако прословљена. Само на йако припремљене хлебове могао се утиснути печат манастира (54); Да се боје не осуше, сваку су љуштурицу посебно обавијали свеже узабраним поточним травама (54); Трећи, немо срезаног језика, проговори... (61); А он, претежак за такав лет, оста да лебди тек стотинак хвати изнад зденца, уйорно непомичног, са жалосно потонулим рукохватом траве бистрице (62); - Баш тако треба! Benissimo! - грцао је магистар Инћиријано, скоро се давећи у каналу, али држећи на високо подигнутим длановима нешто мало воде, а у води искрав осмех госпе Ане, уйраво распетљан од глатког одраза Доминикинових бедара (76); Реgовно обавештавани о приликама у Србаља (...) Млечани напокон решише да задају одсудни ударац... (80); ... отпусти убрусара и пехарника, найола умијених ушију, растера од главе песму вртних чворака (94) итд.

У оваквим случајевима јасно је да глаголски придјев трпни означава радњу која је претходила радњи главног глагола и на њу на неки начин утицала, а прилози који их прате додатно истичу карактер те радње и самим тим „независност” положаја трпног глаголског придјева. Осим прилога трпни придјев може за себе везивати различите врсте допуна, односно одредби, па „и кад су употребљени као атрибути, добивају особину предикације ако уз њих стоји још и каква допуна” (Ђорђић 1931: 131), као у примјерима:

... у бунилу је шапутала жалошћу опхрвана мајка... (47); ... каква својства имају слова писана иерром од дивље гуске, 
а каква она краснописана йером од крагуја (48); Други је известилац донео скупан број монаха и мирјана склоњених $y$ Жичу... (67-68); ... шта да чине са нешто малодушности пронађене $y$ неgариима појединих (68); ...познало се да му је ум потпуно згњецан и да се он управља само према телу - умиваном милованима Ане Дандоло (81); ... прве галије стигоше пред Цариград 24. јуна, палуба претоварених једрим зрневљем светла (133); На широкој тераси, за столом прекривеним майама... седела су два човека (149); У смртно стиснутом кљуну сваке од њих била је по сламка реченица изговорених на тераси резияенщије (150) итд.

Овако употријебљен трпни глаголски придјев јасно представља функционално транспонован реченични члан, који се прилагођава надређеној синтаксеми - супстантиву преузимајући карактеристике правог придјева, док према подређеним члановима показује исходишне (глаголске) рекцијске способности, што га семантичко-синтаксички чини врло блиским функцији предикатског апозитива.

4. Предикатска употреба трпног глаголског придјева

4.1. Без намјере да подробније улазимо у проблематику диференцијације пасивних глаголских времена, јер нам простор то не допушта, у овом раду обухватићемо ипак и примјере са предикатима израженим пасивним облицима грађеним са трпним глаголским придјевом јер сматрамо да је то са стилистичког аспекта занимљиво, будући да смо већ навели да се фреквентном употребом трпног глаголског придјева, па и у облицима пасива, у роману подражава средњовјековни стил.

Примјера употребе несумњивих пасивних личних глаголских облика у Oūcagu uркве Св. Cйаса биљежимо много: 
... када $\delta u$ освећен за архиепископа српског (14); ... нема града из којег није ӣротетеран макар два пута! (18); Висина припрате бu оgређена према Спасовом своду. А он сам, одраније, $\bar{u} о g u \bar{\imath} н y \bar{u}$ у дослуху са сводом изнад овог богохранимог места (25); ... па су они повремено йойрављьнии додавањем тесаних блокова (30); На све стране, кроз прозоре cy йройурани српови, копља, косе или макар црнокорасти ножеви (30); Мада све беше добро расйоређено... (46); ... којом је умивана икона преподобне мученице Евдокије... (46); ... не беху склоюене у Пећ (55); ... да каже - како су ваздигнути бусенови земље расйоређени да се по њима може ходити... (67); Део сувишних бусенова, непотребних за кретање, йрикуйлен је уз стабло једног скрајнутог храста... (67); Ипак, како беше дан када је ойворен црквени прозор, игуман Григорије ... (68); ... он се готово крадом приближио оном месту где је била насликана сцена лествица што спасавају душу и воде међу небеса (68); ... женска је природа сайкана од непредвидљивости (75); У светом Еванђељу је апостолима речено, упамтите добро, штогод свежете на земљи, биће свезано и на небу, и штогод раздрешите на

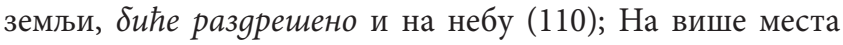
у трпезарији, припрати и цркви беху живойисане зделе, кондири, крчази и ино трпезно посуђе од печене земље, злата, бакра или прозирног стакла, до врха исйунено насликаним љескањем воде (123); ... а на неколицини других беху рукойисани Извори снажног изданка, отом жустрим потезима зографове четкице, таласа очешланих на бистре коврџе (123); Дарови су склаgишиеени у бившем, полуразрушеном здању Арсенала (126) итд.

У наведеним примјерима позиција агенса креће се од имплицитне до потпуно анонимизоване, што представља додатну потврду пасивне употребе трпног придјева специфичну за књижевноумјетнички стил. Примјера у којима је агенс експлициран биљежимо врло мало: Карајем XIV века сваки лов у сну десйойа Сйефана Лазаревића беше

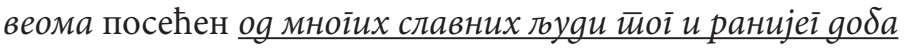




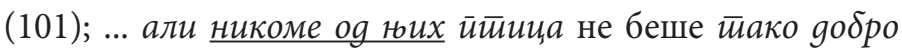
потхрањена срчаношћу (102). Овдје бисмо само још нагласили стилску маркираност овакве употребе глаголских облика, која за циљ има остваривање архаичног и скоро сакралног призвука, као и призвука језика бајки, што се остварује уопште фреквентном употребом аориста и имперфекта, па и њиховог пасивног облика. ${ }^{1}$

4.2. Неупоредиво мање примјера биљежимо са трпним придјевом у функцији предикатива. К. Милошевић издваја неколико критеријума који одређују овакву употребу трпних придјева, од којих ми овдје издвајамо два за које смо у нашем корпусу нашли тек понеки примјер:

1. „Лексичко-іраматиччки: Облици part. pass. нису изведени од прелазних глагола или се више не осјећа њихова веза са основним глаголом - и уопште немају

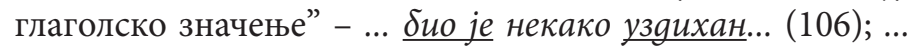

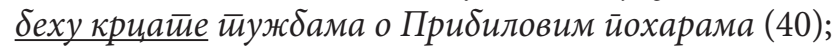

2. „Синтагматска констелација у Lex елементу предиката, и то таква у којој part. pass. Стоји у координативном низу са придјевима, именицама, прилозима или радним придјевима у адјективној функцији” (Милошевић 1973: 426) - Био је наgувен, модар, изіребан, уиееитьан

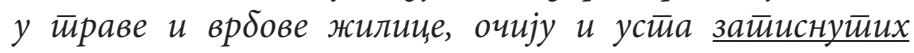
мульем... (113).

Разлози знатно мање фреквентне употребе трпног глаголског придјева у позицији предикатива претпоставили бисмо да се могу довести у везу са његовом изузетно фреквентном атрибутском употребом. Изразиту заступљеност примјера са пасивним предикатом са гла-

1 Овоме у прилог такође говори и облик трпног придјева на -м у примјеру А он сам, оgраније, йоgиīнуй у gослуху са своgом изнаg ової боїохранимої местй. Овакав облик савремени српски језик не познаје. П. Ђорђић га назива трпним глаголским придјевом садашњег времена (више у: Ђорђић 1931). 
голским придјевом трпним такође бисмо довели у везу са језичко-стилским карактеристикама романа, будући да је средњовјековни стил подразумијевао и топос скромности, односно занемаривање ауторског у односу на саму тему, што потпуно одговара пасивној дијатези која по дефиницији подразумијева ненаглашену позицију агенса.

5. У раду смо испитивали колико су критеријуми за одређивање функције глаголског придјева трпног поуздани те да ли се могу изнаћи додатни контекстуални критеријуми који би потпомогли при прецизирању синтаксичке употребе ове морфолошке категорије. Испитујући из литературе издвојене критеријуме атрибутске употребе трпног глаголског придјева на корпусу романа Oūcaga сркве Св. Сйаса, уочили смо да се у одређеном броју примјера може чврсто установити да су трпни глаголски придјеви потпуно категоријално преобразовани, односно адјективизовани (нпр. шитављене коже, обријане ілаве, иреосвећени влаgика), тј. за примјере овакве употребе глаголског трпног придјева може се рећи да су и синтаксички и семантички адјективизовани.

Међутим, у корпусу се издваја много већи број примјера у којима, иако критеријално испуњавају услове адјективизације, налазимо да трпни придјеви нису прешли потпуни семантички еволутивни пут.

Употреба трпног придјева у зависном падежу, према критеријумима, недвосмислено би требало да је чисто атрибутска. Ипак, пронашли смо значајан број примјера у којима је очито да трпни придјеви имају чвршћу везу са супстантивом преко којег су уведени, али је још увијек јасна и њихова релација према глаголу (пр. Иза ове

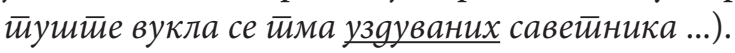

У литератури смо наишли на констатацију да се на атрибутској употреби трпног глаголског придјева највише инсистира уколико он долази у облику одређеног вида. И 
у овом случају нашли смо много више примјера у којима овако употријебљен глаголски придјев трпни чува своју везу са глаголом. Овакве примјере поредили смо са примјерима предикатскоапозитивне употребе трпних придјева и закључили да они такође остварују синтаксичко-сематичку релацију са глаголом, с тим што су они у случају употребе у функцији предикатског апозитива комуникативно и стилски наглашенији (пр. Найољу се

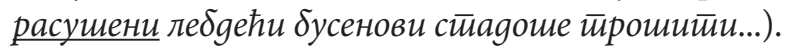

Конкуретност употребе трпног глаголског придјева у функцији предиката исказаног пасивним личним глаголским обликом и предикативном позицијом нисмо подробније испитивали. У корпусу се издваја много већи број примјера јасне употребе трпног глаголског придјева у оквиру пасивне дијатезе.

Дакле, употреба трпног глаголског придјева испитивана је на примјеру корпуса који припада књижевноумјетничком стилу и који при томе подражава средњовјековни стил. У тој историјској епоси партиципи су имали изузетно фреквентну употребу, па сматрамо да је трпном глаголском придјеву у роману Oūcaga uркве Св. Сйаса припала улога једног од језичко-стилских средстава одсликавања саме епохе.

\section{Извори}

Горан Петровић, Оūcaga иркве Св. Сӣaca, Београд: Политика, Народна књига, 2004.

\section{Литература}

Белић 1937: А. Белић, Више семантике! Наш језик, књига бр. V, Београд, 129-135. 
Ђорђић 1931: П. Ђорђић, О старословенским трпним придевима, Јужнословенски филолої, књ. ХІ, Београд, 89-172.

Јовановић 2013: Ј. Јовановић, Обрада трпних придева у дескриптивним речницима српског језика, у: 70 іоgини $\delta$ бліарска акаgемична тексикоірафбия, доклади от Шестата национална конференция с международно участие по лексикография и лексикология, Лилия Крумова-Цветкова, Диана Благоева, Сия Колковска (ур.), София: Българска академия на науките - Институт за български език „Проф. Любомир Андрейчин”, 203-210.

Ковачевић 2015: М. Ковачевић, О реченици и юеним члановима, Београд: Јасен.

Милошевић 1973: К. Милошевић, Темпорално значење и синтаксичка вриједност конструкција Cop (praes. perf.) - part. pass. у српскохрватском језику, Јужнословенски филолоі XXX, Београд, 423-437.

PMC 2011: Речник сриискої језика, Нови Сад: Матица српска.

Станојчић/Поповић 2014: Ж. Станојчић, Љ. Поповић, Граматика српског језика за гимназије и средюе школе, Београд: Завод за уџбенике.

Суботић/Петровић 2000: Lj.Subotić, V. Petrović, Apozitivni i/ili predikativni atribut, Јужнословенски филолої LVI, Београд, 1141-1160.

Танасић 2012: С. Танасић, Агенс у пасивним реченицама у савременом српском језику, Јужнословенски филолої LXVIII, Београд, 71-90. 
Svetlana Panić

\section{DIE SYNTAKTISCHEN FUNKTIONEN DES VERBALEN ADJEKTIVS LEIDEFORM IM ROMAN DIE BELAGERUNG DER KIRCHE VON ST. HEIL VON GORAN PETROVIC}

Das verbale Adjektiv Leideform deutet schon im Titel auf zwei Funktionen - die verbale und die adjektive. Die verbale Funktion verbunden mit der passiven Diathese, und die adjektive Funktion verbunden mit der Funktion des Attributs. Aber dies sind nicht die einzigen Funktionen des verbalen Adjektivs in Leideform, sondern sie durchkreuzen sich in gewisser Weise in der Funktion des prädikaten Appositivs.

In dieser Arbeit analysierten wir die Anwendbarkeit der Kriterien der Abgrenzung der Funktionen des verbalen Adjektivs Leideform auf Beispielen aus dem Roman Die Belagerung der Kirche von St. Heil von Goran Petrovic und haben festgestellt, dass in der geringen Anzahl von Beispielen man wahrnehmen kann, dass die verbalen Adjektive Leideform total kategorisch umwandelt wurden, beziehungsweise adjektivisiert, dh. für Beispiele dieser Verwendung des verbalen Adjektivs Leideform kann gesagt werden, dass sie sowohl syntaktisch und semantisch adjektivisiert wurden. Im Korpus hebt sich eine viel größere Anzahl von Beispielen ab, in denen, obwohl sie im Kriterium die Voraussetzungen der Adjektivierung ausfüllen, erkennt man, dass die Adjektive Leideform keinen vollständigen Wegder semantischen Evolution zurückgelegt hat, beziehungsweise ihre Beziehung mit dem Verb des Kontextes kann leicht bestimmt werden. Wir erachten, dass der Grund dafür von stilistischer Natur ist, weil in dem Roman Die Belagerung der Kirche von St. Heil der mittelalterliche Stil nachgeahmt wird, der unter anderem die weit verbreitete Verwendung des Partizips impliziert, in der primären partizipialen Bedeutung.

Stichwörter: verbales Adjektiv Leideform, Attribut, prädikates Appositiv, passive Diathese, nominales Prädikat 